\title{
ЗАСТОСУВАННЯ КВЕСТУ ЯК ТЕХНОЛОГІЇ ПРАКТИКО- ОРІЄНТОВАНОГО НАВЧАННЯ СТУДЕНТІВ МЕДИЧНИХ ВИШІВ
}

\author{
L. O. Shevchyk ${ }^{1}$, N. Ya. Kravets ${ }^{2}$ \\ ${ }^{1}$ V. Hnatiuk Ternopil National Pedagogical University, \\ ${ }^{2}$ I. Horbachevsky Ternopil State Medical University

\section{QUEST APPLICATION AS TECHNOLOGIES OF PRACTICAL ORIENTED EDUCATION OF STUDENTS OF MEDICAL UNIVERSITIES}

\begin{abstract}
Мета роботи - обгрунтування доцільності застосування квест-технологій з метою урізноманітнення навчального процесу, активізації пізнавальної діяльності, розширення сфери інтересів студентів медичних вишів України.

Основна частина. У процесі роботи зі студентами найбільш доречно залучати такі форми спільного обговорення проблеми і вироблення загального рішення, котрі дозволяють не лише висловлювати свою думку, погляд і оцінку, а й почути аргументи партнера, часом відмовитися від своєї точки зору або істотно змінити її.

Однією з таких технологій, яка вчить знаходити необхідну інформацію, піддавати її аналізу, систематизувати та вирішувати поставлені задачі, власне і є квест.

Висновки. Завдяки проведенню інтелектуального квесту студенти мають можливість не лише перевірити власний рівень залишкових знань, дізнатися чимало нових цікавих фактів, а й можуть структурувати вже наявні знання.

Роль викладача в ході квесту зводиться до коректного формування змісту завдань; підготовки та розподілення ролей для студентів; створення сприятливих умов у групі для висловлювання власної думки кожного з учасників; ознайомлення студентів з чітко сформованими правилами інтерактивної гри та спрямування їх у правильну сторону розвитку подій.
\end{abstract}

Ключові слова: інноваційна освітня діяльність; інтерактивні форми навчання; вищі навчальні заклади; навчальний процес; квест-технології; медична освіта; найпростіші.

The aim of the work - to substantiate the feasibility of using quest-technologies in order to diversify the educational process, activate cognitive activity, expand the sphere of interests of students of medical universities of Ukraine.

The main body. In the process of working with students it is most appropriate to involve such forms of joint discussion of the problem and the development of a general solution that allows not only to express their opinions, views and assessments, but also to hear the arguments of the partner, sometimes to abandon their point of view or substantially change it.

Quest is one of these technologies, which teaches to find the necessary information, to analyze it, to systematize and solve the tasks. Through the conduct of the intellectual quest, or at least its elements, using thematic posters, students have the opportunity not only to check their own level of residual knowledge, to learn a lot of new interesting facts, but also can structure existing knowledge.

Conclusions. Through the conduct of the intellectual quest, or at least its elements, using thematic posters, students have the opportunity not only to check their own level of residual knowledge, to learn a lot of new interesting facts, but also can structure existing knowledge.

Although the role of the teacher during the quest is minor, but on his own should be the process of preparation and distribution of roles for students. The task of the teacher is to create favorable conditions in the group for expressing the opinion of each participant, to familiarize students with clearly defined rules of the interactive game and direct students to the right side of the development of events.

Key words: innovative educational activity; interactive forms of education; higher educational institutions; educational process; quest-technologies; medical education; the simplest.

Вступ. У сучасних умовах реформування системи освіти України набула актуальності проблема професійної підготовки майбутніх фахівців. Виходячи з усвідомлення цього, розуміємо - навчання у вищих навчальних закладах повинно бути методично

(с Л. О. Шевчик, Н. Я. Кравець обгрунтованим та досконало продуманим. У цьому контексті особливої актуальності та визначального значення набувають методика, методи, технології та техніки викладання дисциплін у вишах України [4].

Процес навчання у вищих закладах освіти складний, багатогранний процес. Для кращого 
запам'ятовування та відтворення інформації поряд навіть із найталановитішим поясненням необхідна напружена розумова робота студента, його активність, вміння інтерпретувати ситуацію. Все це забезпечує підготовку висококваліфікованих працівників у різних галузях, успішних та конкурентоспроможних на європейському і світових ринках праці, спеціалістів нового типу, чутливих до вимог сучасного суспільства, здатних шукати рішення у співпраці з колегами [10].

Таким чином, в умовах трансформаційних змін у вищій школі потребують постійного ретельного вивчення питання набуття досвіду інноваційної освітньої діяльності, покращення змісту інтерактивних форм навчання, специфіки їх використання у вищих навчальних закладах [2].

Мета роботи - обгрунтування доцільності застосування квест-технологій з метою урізноманітнення навчального процесу, активізації пізнавальної діяльності, розширення сфери інтересів студентів медичних вишів України.

Основна частина. Аналіз останніх досліджень і публікацій надає можливість дійти висновку, що проблемам застосування сучасних інтерактивних технологій у навчальному процесі було присвячено дослідження науковців [6, 7], які вивчали теоретичні та практичні, а саме педагогічні, психологічні, соціально-психологічні, методологічні аспекти останніх. В якості інтенсивних педагогічних технологій у навчанні особливе місце займають ігрові технології [6].

Аналіз останніх досліджень і публікацій надає можливість дійти висновку, що проблемам застосування сучасних інтерактивних технологій в освітньому процесі присвячені дослідження знаних в Україні науковців [6, 7].

У роботах вітчизняних та зарубіжних науковців активізувався процес вивчення навчальної ролі квест-технологій [3, 9].

У процесі роботи зі студентами найбільш доречно залучати такі форми спільного обговорення проблеми і вироблення загального рішення, котрі дозволяють не лише висловлювати свою думку, погляд і оцінку, а й почути аргументи партнера, часом відмовитися від своєї точки зору або істотно змінити їі.

Однією з таких технологій, яка вчить знаходити необхідну інформацію, піддавати її аналізу, систематизувати та вирішувати поставлені задачі, власне і $€$ квест [8].

Квест дозволяє розвивати активне пізнання на заняттях, сприяє розвитку мислення, допомагає долати проблеми та труднощі, уміти застосовувати набуті знання на практиці у нестандартних ситуаціях, тобто актуалізувати їх, вчить мислити логічно, розвиває інтерактивні здібності [5, 6].

Квест ефективний у тому випадку, якщо обговорюється певна проблема в цілому, про яку студенти мають первинні уявлення, одержані раніше на заняттях або з життєвого досвіду. Крім того, теми, які обговорюються, не мають бути закритими або дуже вузькими.

У процесі підготовки сценарію важливо визначити, до якої саме технології належить запропонований квест. Без сумніву, за рівнем застосування він $€$ предметним, призначеним для вдосконалення навчання мікробіології у медичних вишах; науковим за філософською спрямованістю; за науковою концепцією засвоєння досвіду - розвивальним; за типом організації й управління пізнавальною діяльністю - ігровим.

Запропонований квест проводиться студентами II курсу в рамках опрацювання теми "Морфологія та структура спірохет, актиноміцетів, грибів, найпростіших” у модулі “Морфологія і структура прокаріотів та паразитичних еукаріотів”. Самостійна робота $[1,8]$.

Матеріал детально вивчений студентами ще на першому курсі, під час засвоєння теоретичного матеріалу з дисципліни "Медична біологія" в розділі III "Популяційно-видовий, біогеоценотичний і біосферний рівні організації життя”, під час практичних занять на тему: 1 . Тип Саркоджгутикові (Sarcomastigophora): клас Справжні амеби (Lobozea). Тип Війконосні (Ciliophora): клас Війчасті (Litostomatea). 2. Тип Саркоджгутикові (Sarcomastigophora): клас Тваринні джгутикові (Zoomastigophora). 3. Тип Апікомплексні (Apicomplexa): клас Споровики (Sporozoea).

\section{Змістова лінія квесту}

Mета: узагальнити та закріпити знання студентів про будову й особливості життєдіяльності паразитичних найпростіших; формувати науковий світогляд студентів, через який вони осмислюють і оцінюють різноманіття паразитичних найпростіших та їхній вплив на людину; формувати навички самостійної роботи, аналізу й узагальнення; стимулювати творчу активність студентів; виховувати їхню екологічну свідомість.

Форма проведення: інтелектуально-розвивальна гра-квест.

Обладнання: інформаційні плакати, маршрутні листи, годинник, мікроскопи, мікропрепарати. 
(У випадку проведення квесту на виїзді фотографіï, або презентації “Видове різноманіття тварин”.)

Тривалість гри: 1 год.

Місце проведення: кафедра мікробіології, вірусології та імунології ТДМУ імені І. Я. Горбачевського.

Час проведення: у позааудиторний час.

Попередня підготовка: виготовлення інформаційних плакатів; оформлення і підготовка приміщень до заняття; підготовка маршрутних листів та бланків відповідей для кожної команди, завдання й необхідні матеріали для їхнього виконання на кожному етапі.

Правила проведення. Студенти об’єднуються у шість команд. Кожна команда отримує власний маршрутний лист (додатки), у який необхідно вписати імена членів команди на час старту.

Щоб досягти максимальної справедливості в розподілі маршрутних листів, на початку квесту командам пропонують розгадати кросворд “Найпростіші”. Команда, яка впорається із завданням першою, отримує маршрутний лист першої команди і так далі.

У маршрутному листі зазначено відправну точку, тобто номер інформаційного плаката, із якого необхідно розпочати гру, а також завдання. Після завершення змагань у маршрутному листі кожної команди вказується час фінішу, а лист здається на перевірку викладачеві.

Під час оцінювання команд братимуться до уваги не лише правильні відповіді, а й час, потрачений на виконання завдання. Перевірка здійснюється за бланками з відповідями. Кожне завдання оцінюється у два бали (1 бал за правильну відповідь та

\section{Список літератури}

1. Авдєєнко А. П. Інтенсифікація навчального процесу та організація самостійної роботи студентів / А. П. Авдєєнко, Л. В. Дементій, О. Є. Поляков // Проблеми освіти. 2001. - Вип. 24. - С. 108-111.

2. Бистрова Ю. В. Інноваційні методи навчання у вищій школі України / Ю. В. Бистрова // Право та інноваційне суспільство. - 2015. - № 1 (4). - С. 27-31.

3. Буданова Н. Г. Методика проведения учебных занятий с применением педагогической технологии “Квест” (метод проектов) / Н. Г. Буданова // Фестиваль педагогических идей “Открытый урок” [Электронный peсурс]. - Режим доступа : http://xn--i1abbnckbmcl9fb. xn--p1ai/\%D1\%81\%D1\%82\%D0\%B0\%D1\%82\% D1\%8C\%D0\%B8/662352/.

4. Головко Н. І. Методика викладання у вищій школі [Електронний ресурс] / Н. І. Головко. - Режим доступу : http : //iht.univ.kiev.ua/iht-lectures/ .
1 бал за правильне визначення номера наступного плаката). Практичне завдання передбачає організацію роботи з мікроскопом, визначення виду, наукової назви, систематичного положення паразита та назву захворювання, збудником якого є паразит. За правильне виконання всіх завдань команда може отримати 11 балів. (У випадку проведення квесту на виїзді практичне завдання можна замінити на конкурси “Наукова бібліотека”, “Фотолабораторія”.)

Важливим етапом квесту є рефлексія. Власне в процесі проходження завдань студенти вчаться формулювати проблему, планувати свою діяльність, критично мислити, вирішувати складні проблеми, зважувати альтернативні думки, самостійно приймати продумані рішення, приймати на себе відповідальність за їх реалізацію.

Після проходження всіх етапів квесту учасники команд збираються для оголошення результатів. Переможцем стає команда, яка набирає найбільшу кількість балів за виконані завдання.

Висновки. Завдяки проведенню інтелектуального квесту студенти мають можливість не лише перевірити власний рівень залишкових знань, дізнатися чимало нових цікавих фактів, а й можуть структурувати вже наявні знання.

Роль викладача в ході квесту зводиться до коректного формування змісту завдань; підготовки та розподілення ролей для студентів; створення сприятливих умов у групі для висловлювання власної думки кожного з учасників; ознайомлення студентів з чітко сформованими правилами інтерактивної гри та спрямування їх у правильну сторону розвитку подій.

5. Мішагіна О. Д. Використання квесту як засобу активізації навчальної діяльності учнів [Електронний ресурс] / О. Д. Мішагіна // Форум педагогічних ідей “Урок”. - Режим доступу : http://osvita.ua/school/lessons_ summary/edu_technology/34730/.

6. Нові технології навчання : наук.-метод. зб. Вип. 63, ч. 2 / редкол. О. П. Гребельник, Я. Я. Болюбаш, І. А. Шелест [та ін.]. - К. : ІІТЗО МОН України, 2010. - 183 с.

7. Пометун О. І. Інтерактивні технології навчання: Сучасний урок / О. І. Пометун, Л. В. Пироженко ; за ред. О. І. Пометун. - К. : Видавництво. А.С.К., 2004. - 192 с. 8. Практична мікробіологія [навч. посіб.] / С. І. Климнюк, І. О. Ситник, М. С. Творко, В. П. Широбоков. Тернопіль : Укрмедкнига, 2004. - 440 с.

9. Сокол І. М. Квест: метод чи технологія / І. М. Сокол // Комп’ютер у школі та сім’ї навчання. - 2012. - № 2. C. 28-31. 
10. Сучасні освітні технології у вищій школі : матеріали міжнар. наук.-метод. конф. (Київ, 1-2 листопада
2007 року) : тези доповідей : у 2 ч. Ч. 2 / відп ред. А. А. Мазаракі. - К. : Київ. нац. торг.- екон. ун-т, 2007. - 259 с.

\section{References}

1. Avdieienko, A.P., Dementii, L.V., \& Poliakov, O.Ie. (2001). Intensyfikatsiia navchalnoho protsesu ta orhanizatsiia samostiinoi roboty studentiv [Intensification of educational process and organization of independent work of students]. Problemy osvity - Problems of Education, 24, 108-111 [in Ukrainian].

2. Bystrova, Iu.V. (2015). Inovatsiini metody navchannia u vyshchii shkoli Ukrainy [Innovative teaching methods in Ukrainian high shool]. Pravo ta innovatsiine suspilstvo Law and Innovative Society, 1 (4), 27-31 [in Ukrainian].

3. Budanova, N.G. (2016). Metodika provedeniya uchebnykh zanyatiy s primeneniem pedagogicheskoy tekhnologii "Kvest" (metod proektov) [The methodology for conducting training sessions using Pedagogical Technology Quest (project method)]. Festival pedagogicheskikh idey "Otkrytyy urok" - Festival of Pedagogical Ideas "Open lesson". - Retrieved from: http:// открытый урок.рф/статтьи /662352/ [in Russian].

4. Holovko, N.I. (2013). Metodyka vykladannia u vyshchii shkoli [Teaching method in high school]. - Retrieved from: http: //iht.univ.kiev.ua/iht-lectures/ [in Ukrainian].

5. Mishahina, O.D. (2013). Vykorystannia kvestu yak zasobu aktyvizatsii navchalnoi diialnosti uchniv [Use of the quest as a means of enhancing the student's learning activities]. Forum pedahohichnykh idei "Urok" - Forum of pedagogical ideas “Lesson”. - Retrieved from: http://

Електронна адреса для листування: kravetc@i.ua osvita.ua/school/lessons_summary/edu_technology/34730/ [in Ukrainian].

6. Hrebelnyk, O.P., Boliubash, Ia.Ia., \& Shelest, I.A. (2010). Novi tekhnolohii navchannia [New learning technologies]. Naukovo-metodychnyi zbirnyk - Scientific and Methodical Collection, 63, (2). Kyiv: IITZO MON Ukrainy [in Ukrainian].

7. Pometun, O.I., \& Pyrozhenko, L.V. (2004) Interaktyvni tekhnolohii navchannia: Suchasnyi urok [Interactive Learning Technologies: Contemporary Lesson]. Pometun, O.I. (Ed.). Kyiv: Vydavnytstvo A.S.K. [in Ukrainian].

8. Klymniuk, S.I., Sytnyk, I.O., Tvorko, M.S., \& Shyrobokov, V.P. (2004.) Praktychna mikrobiolohiia [navch.posib.] [Practical microbiology [tutorial]]. Ternopil: Ukrmedknyha [in Ukrainian].

9. Sokol, I.M. (2012). Kvest: metod chy tekhnolohiia [Quest: method or technology]. Kompiuter u shkoli ta simi navchannia - Computer at School and Family Learning, 2, 28-31[in Ukrainian].

10. Mazaraki, A.A. (2007). Suchasni osvitni tekhnolohii u vyshchii shkoli [Modern educational technologies at higher school]. Materialy mizhnar. nauk.-metod. konf. (Kyiv, 1-2 lystopada 2007 roku): Tezy dopovidei: U 2 ch,Ch. 2 - Internship Materials Sci. Method. Conf. (November, 1-2). Kyiv: Kyiv. nats. torh.- ekon. un-t [in Ukrainian]. 